\title{
Pre-service Science Teachers' Cognitive Structure about Some Epidermal Structure in Plant
}

\author{
Yeşim Yener \\ Department of Elementary Education, Faculty of Education, Abant İzzet Baysal University, Turkey
}

Copyright $\bigcirc 2017$ by authors, all rights reserved. Authors agree that this article remains permanently open access under the terms of the Creative Commons Attribution License 4.0 International License

\begin{abstract}
The main focus of this study is to determine pre-service science teachers' cognitive structure about trichome and stoma through two alternative assessment techniques: metaphor and word association test. The study was conducted with 35 pre-service science teachers. Word association test given stoma and trichome as stimulant words was applied. Also they were asked to complete these sentences 'Stoma is like/similar to ... Because ...' and 'Trichome is like/similar to ... Because ....' The data obtained from both techniques were analysed according to the content analysis, frequency tables were prepared and divided into categories. With the help of these categories, the cognitive structures of pre-service science teachers and also misconceptions they had were revealed. Consequently, it was suggested that using metaphors in conjunction with word association test for determining of the cognitive structure of students in any subject would be complementary factor for each other's.
\end{abstract}

Keywords Cognitive Structure, Metaphor Technique, Pre-service Science Teacher, Word Association Test

\section{Introduction}

Biology, which is a very interesting field as it examines the life of living organism, also includes subjects which are difficult to be understood by students. Therefore, it is a difficult field to teach and to be learned. This situation also affects the complete formation of students' cognitive structures (Cimer 2012; Lukin 2013). The cognitive structure shows the relationships of the concepts that are recorded in the long-term memory by a student with each other and is a hypothetical structure (Smith, Blakeslee and Anderson 1993). If this structure is formed strongly, the connection of long-term concepts placed in memory with other relevant concepts is established, and thus meaningful learning has been performed.

Gilbert, Boulter and Rutherford (1998) emphasize that it is quite difficult to explain the cognitive structures of individuals but the key concepts reveal the cognitive structures of individuals. Some techniques are used to reveal the concepts in the cognitive structure and the relationships between these concepts. Some of these techniques are word association test, structured grid, concept maps, conceptual change texts and analogies (Bahar \& Özatl1, 2003; Bahar, Ozel, Prokop and Usak 2008). It is inevitable to talk about the metaphors when it comes to the analogy. Both analogies and metaphors compare two cases and indicate their similar aspects, but there are minor differences between them. While two cases are explicitly compared in the analogy, metaphors make comparison implicitly (Duit 1991). Metaphors are defined as a part of the scientific process and have been effective tools in the process of reasoning on unknowns on the basis of the known. Although the comparisons used in this sense are described as analogies, they often emerge as the metaphors in the literature (Demirci-Güler 2012). The word association tests are used to determine whether the connections between concepts in the student's cognitive structure and the relationships between concepts in the student's long-term memory are sufficient, and are used in many studies (Bahar, Johnstone and Sutcliffe 1999; Cardellini and Bahar 2000). In this test, it is assumed that the sequential response to the stimulus word given by students from their long-term memory reveals the connections between concepts in the cognitive structure. The less distance between two concepts is, the more tightly associated these two concepts are and the faster the response is (Bahar and Özatlı 2003).

Stoma and trichome found in plants are structures belonging to epidermal layer of leaves. These structures have indirect function for producing oxygen which has vital importance for the survival of living things. The fact that well-known of these structures is very important in terms of understanding the issue of photosynthesis in which lots of misconceptions have seen (Canal 1999; Tekkaya and Balcı 2003; Marmaroti and Galanopoulou 2006; Köse 2008). Moreover in the literature review carried out, no study in which pre-service science teacher' conceptual structures related to stoma and trichome from 
plantal structures are investigated has been encountered. Therefore in this study, it was aimed to identify pre-service science teacher' cognitive structures related to these concepts by using word association test and metaphor together.

\section{Method}

In this study, carried out in spring term of 2015-2016 academic years, pre-service science teachers' cognitive structures related to "stoma" and "trichome" and in this context the misconceptions on these issues have been identified in detail with the qualitative research method. In this method, the main purpose is to present a detailed descriptive and realistic status of this subject studied (Yıldırım and Şimșek 2008). In this study the data obtained were also given comprehensively.

\subsection{Study Group}

The study was carried out with 35 pre-service science teachers (25 female and 10 male) studying in the 2 nd grade of Science Teaching Department at a University in Black Sea Region. Criterion sampling, one of the purposeful sampling methods, was used in the creation of the study group (Yıldırım \& Şimşek, 2008). The fact that pre-service science teachers received general biology course, they voluntarily participated in the study, and easy accessibility to the researcher are the criteria in the creation of the study group in this study.

\subsection{Data Collection Tools}

Word association test: In this study, "stoma" and "trichome" were given as stimulus words to pre-service science teachers to complete the word association test. In order to avoid the risk of chain response, the paper on which these words were written as one under the other was given to pre-service science teachers, and they were asked to write the first 10 words brought to their minds by these words within 30 seconds. (Bahar et al., 1999; Bahar \& Özatl1, 2003).

Metaphor technique: In this technique, pre-service science teachers who participated in the research were asked to complete the sentences of "Stoma is like/similar to........ Because .........." and "Trichome is like/similar to........ Because ...........". A full course hour (50 minutes) was given as a time to complete it. Before starting to write sentences, pre-service science teachers were informed about what the metaphor is, for what purposes it is used through some examples. The papers consisting of the sentences which were collected from pre-service science teachers constituted the basic data source.

\subsection{Data Analysis}

Before starting the data analysis, pre-service science teachers' papers were encoded by numbering from 1 to 35 . The data obtained from the word association test were analyzed using the number of words, number of responses and semantic relation technique (Atasoy 2004). The words which were regarded as irrelevant or were used once were not evaluated. The words were categorized according to their semantic relations, and their frequencies were achieved (Kurt and Ekici 2013).

The data obtained from the metaphor technique were evaluated in terms of whether they were expressed explicitly, the significance of rationale and whether a single metaphor was used. The metaphors suggested by pre-service science teachers were categorized by their common features and their frequencies achieved.

Although the categories obtained at the end of the word association test comprised the categories obtained by the metaphor technique, categories were named by different names because of the difference of both measurement tools.

\section{Two processes were followed to ensure the validity and reliability of the research results:}

1. The coding of the data and the data analysis process were described in detail (Hruschka et al., 2004).

2. The codes of two researchers who are experts in their field and the categories regarding the codes were compared to verify whether the concepts which were gathered under the conceptual category achieved in the data analysis represent the conceptual categories in question. The reliability of the data analysis performed in this way was calculated using [Agreement/ (Agreement + Disagreement) x 100] formula (Miles \& Huberman, 1994). While the average reliability coefficient between the coders for the word association test was calculated as $94 \%$ for the concept of "stoma" and as $90 \%$ for the concept of "trichome", it was calculated as $92 \%$ for the concept of "stoma" and as $95 \%$ for the concept of "trichome" in the metaphor technique.

\section{Findings}

The findings regarding the concepts of "stoma" and "trichome" which were obtained with the word association test and metaphor technique are presented in this section.

\subsection{The Findings Obtained for the "Stoma" Concept with the Word Association Test}

The words which were repeated once by pre-service science teachers were excluded from the analysis (Kostova and Radoynovska 2008). The remaining 30 different words 
were divided into 6 categories, and a total of 324 response words were obtained (Table 1).

Table 1. Distribution of pre-service science teacher' cognitive structures about "stoma" by categories

\begin{tabular}{|c|c|c|}
\hline Categories & $\begin{array}{l}\text { Concepts under categories and } \\
\text { their frequencies }\end{array}$ & $\begin{array}{c}\text { Total } \\
\text { frequencies of } \\
\text { categories }\end{array}$ \\
\hline $\begin{array}{l}\text { Its working } \\
\text { mechanism }\end{array}$ & $\begin{array}{c}\text { “opening and closing” (38) } \\
\text { “osmotic pressure” (15) } \\
\text { "turgor pressure” (12) } \\
\text { "pH” (11) } \\
\text { “temperature” (8) } \\
\text { "sun light” (7) } \\
\text { "sugar" (6) } \\
\text { "plasmolysis" (6) } \\
\text { "enzym" (6) } \\
\text { "photosynthesis” (5) } \\
\text { "humidity" (2) }\end{array}$ & 116 \\
\hline $\begin{array}{l}\text { Its anatomical } \\
\text { structure }\end{array}$ & 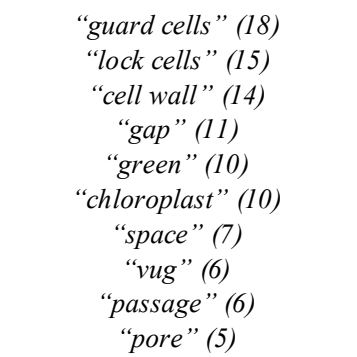 & 102 \\
\hline Its region & $\begin{array}{l}\text { “plant” (19) } \\
\text { “leaf” (15) } \\
\text { “epiderm" (8) }\end{array}$ & 42 \\
\hline Its permeability & $\begin{array}{c}\text { “CO } \mathrm{CO}_{2} \text { (19) } \\
\text { “ } \mathrm{O}_{2} ”,(16) \\
\text { “nutrition” (5) }\end{array}$ & 40 \\
\hline Its function & $\begin{array}{c}\text { "gas exchange" (14) } \\
\text { "lenticel" (8) }\end{array}$ & 22 \\
\hline Its shape & “bean” (2) & 2 \\
\hline Total & 30 words & 324 \\
\hline
\end{tabular}

The "its working mechanism" category emerged as the first category among the obtained words $(\mathrm{f}=116)$. In this category, most of the pre-service science teachers focused on the opening and closing mechanism of stoma and the pressures affecting this mechanism.

In the second category, pre-service science teachers made the associations related to "its anatomical structure" $(\mathrm{f}=102)$; although most of the pre-service science teachers mainly focused on the cells that make up the stoma, the rest of them focused on the space between the cells that make up the stoma.

In the third category, pre-service science teachers suggested response words related to the "its region where the stoma exists" ( $\mathrm{f}=42$ ). Here, the word of "plant" was mostly suggested by pre-service science teachers because stoma is a structure peculiar to plants. This was followed by the words of "leaf" and "epidermis".
The fourth category was the "its permeability" category $(\mathrm{f}=40)$. In this category, pre-service science teachers mostly suggested the word of $\mathrm{CO}_{2}$ and then the word of $\mathrm{O}_{2}$ considering the substances passing through the pore of stoma.

The fifth category was "its function" category $(\mathrm{f}=22)$. The words of "gas exchange" and "lenticel" were the prominent words in this category.

The sixth category was "its shape" category $(\mathrm{f}=2)$. The word of "bean" was suggested by pre-service science teachers because the shape of the guard cells looks like it.

\subsection{The Findings Obtained for the "Stoma" Concept with the Metaphor Technique}

Pre-service science teachers suggested 16 metaphors related to the "stoma" concept, and 3 of these metaphors were not evaluated because of their meaningless rationale. The metaphors which were not included for evaluation are "bee", "security guard" and "customs officer". The suggested 13 metaphors were gathered under three categories including "working mechanism similarity", "function similarity" and "shape similarity", and their frequencies were achieved (Table 2).

Table 2. Distribution of metaphors representing pre-service science teachers about "stoma" by categories

\begin{tabular}{|c|c|c|}
\hline Categories & $\begin{array}{l}\text { Metaphors under categories } \\
\text { and their frequencies }\end{array}$ & $\begin{array}{c}\text { Total } \\
\text { frequencies of } \\
\text { categories }\end{array}$ \\
\hline \multirow{8}{*}{$\begin{array}{l}\text { Working } \\
\text { mechanism }\end{array}$} & “door” (6) & \multirow{8}{*}{17} \\
\hline & “Venus flytrap” (3) & \\
\hline & "lift door" (3) & \\
\hline & “water gate” (1) & \\
\hline & “eyelid” (1) & \\
\hline & "cardiac valve" (1) & \\
\hline & “stomach" (1) & \\
\hline & “curtain” (1) & \\
\hline \multirow{4}{*}{$\begin{array}{l}\text { Function } \\
\text { similarity }\end{array}$} & “lenticel” (4) & \multirow{4}{*}{10} \\
\hline & "noise” (2) & \\
\hline & "window" (2) & \\
\hline & "trachea" (2) & \\
\hline Shape similarity & “bean” (5) & 5 \\
\hline Total & 13 metaphors & 32 \\
\hline
\end{tabular}

The metaphors suggested by the great majority of pre-service science teachers $(\mathrm{f}=17)$ were gathered under the "working mechanism" category, the first category. Pre-service science teachers emphasized the opening and closing mechanism of the stoma in their metaphors. The metaphor of "door" in this category is the metaphor with the highest frequency, and an example of this metaphor is as follows;

"Stoma is like a door, because stoma should be opened and closed in the plant for the inlet and outlet of gas and water vapor. The door also is a tool that we use to get in and get out". 
The remaining metaphors were gathered under the "function similarity" and "shape similarity" categories, and "lenticel" and "bean" were mostly repeated metaphors in these categories.

When the evaluated both techniques together, the model about the cognitive structure of pre-service science teachers on the concept of stoma was created (Figure 1).
The categories obtained from word association test and metaphor technique were shown in this model. Moreover common 3 categories in both techniques, dominant category in these common categories, the most emphasized function of stoma, the category in which misconception was determined and the most repetitive common words in both techniques were also shown in this model.

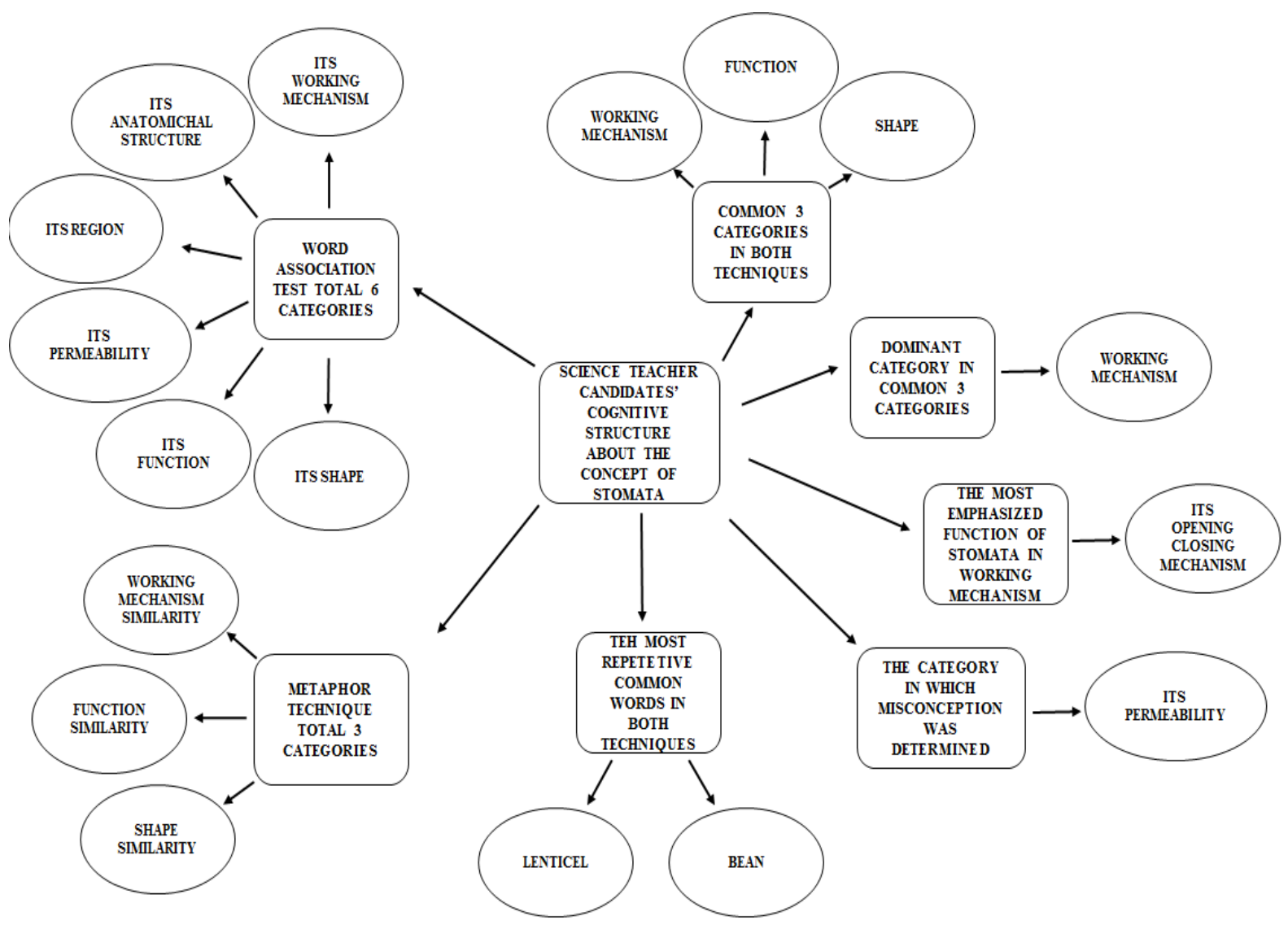

Figure 1. Pre-service science teachers' cognitive structure about stoma 


\subsection{The Findings Obtained for the "Trichome" Concept with the Word Association Test}

The words which were suggested once related to "trichome" concept from epidermal structures were excluded, and the remaining 27 different words were divided into 6 categories, and a total of 320 response words were obtained (Table 3 ).

Table 3. Distribution of pre-service science teachers' cognitive structures about "trichome" by categories

\begin{tabular}{|c|c|c|}
\hline Categories & $\begin{array}{c}\text { Concepts under categories and } \\
\text { their frequencies }\end{array}$ & $\begin{array}{c}\text { Total } \\
\text { frequencies of } \\
\text { categories }\end{array}$ \\
\hline Its function & $\begin{array}{c}\text { "protective" (49) } \\
\text { “absorption" (28) } \\
\text { "pull” (18) } \\
\text { "secret" (16) } \\
\text { "cover" (16) } \\
\text { “water and minerals" (7) } \\
\text { “adsorption" (6) } \\
\text { "pollination" (5) } \\
\text { “defence” (2) } \\
\text { "shield" (2) }\end{array}$ & 149 \\
\hline Its region & $\begin{array}{c}\text { "plant” (25) } \\
\text { “leaf” (20) } \\
\text { “dog” (10) } \\
\text { “peach” (9) } \\
\text { "stinging nettle” (7) } \\
\text { "root” (7) } \\
\text { “outer surface” (6) }\end{array}$ & 84 \\
\hline Its origin & $\begin{array}{c}\text { “epiderm” (20) } \\
\text { “permanent tissue” (5) } \\
\text { “meristem”(2) }\end{array}$ & 27 \\
\hline Its liveliness & $\begin{array}{c}\text { "live” (12) } \\
\text { "lifeless" (10) }\end{array}$ & 22 \\
\hline Its shape & $\begin{array}{l}\text { "bulge" (13) } \\
\text { "thorn" (7) }\end{array}$ & 20 \\
\hline Feeling created & $\begin{array}{l}\text { “itching" (8) } \\
\text { "pain" (5) } \\
\text { "soft" (5) }\end{array}$ & 18 \\
\hline Total & 27 words & 320 \\
\hline
\end{tabular}

The "its function" category emerged as the first category among the obtained words ( $\mathrm{f}=149$ ). In this category, most of the pre-service science teachers focused on "protection" which is one of the functions of the trichome.

In the second category, pre-service science teachers made the associations related to the "its region" $(\mathrm{f}=84)$. In this category, the word of "plant" was mostly suggested, and this was followed by "leaf" and some plants with trichome.

In the third category, pre-service science teachers suggested response words related to the "its origin" ( $\mathrm{f}=27$ ). The word of "epiderm" was mostly suggested by pre-service science teachers because trichomes are formed by the change of epiderm.

The fourth category is the "its liveliness" category $(\mathrm{f}=22)$. In this category, participants repeated the words of "live" and "lifeless" almost equally in number.

The fifth category is the "its shape" category $(\mathrm{f}=20)$. In this category, most of the pre-service science teachers considered trichome as a "bulge".

The sixth category is the "feeling created" category $(\mathrm{f}=18)$. In this category, pre-service science teachers mostly suggested the word of "itching".

\subsection{The Findings Obtained for the "Trichome" Concept with the Metaphor Technique}

Pre-service science teachers suggested 18 metaphors for the "trichome" concept. The suggested 18 metaphors were gathered under 2 categories including "function similarity" and "shape similarity", and their frequencies were achieved (Table 4).

Table 4. Distribution of metaphors representing pre-service science teachers about "trichome" by categories

\begin{tabular}{ccc}
\hline Categories & $\begin{array}{c}\text { Metaphors under categories } \\
\text { and their frequencies }\end{array}$ & $\begin{array}{c}\text { Total } \\
\text { frequencies of } \\
\text { categories }\end{array}$ \\
\hline "mother" (8) & \\
"hair" (5) & \\
"blanket" (3) & \\
"shield" (3) \\
"eyelash" (2) \\
"wire netting" (2) \\
"friend" (1) \\
"bodyguard" (1) \\
"pet dog" (1) \\
"skin" (1) \\
"roof" (1) \\
"pipette"(1) \\
"horn" (1) \\
"candle" (1) \\
"minaret" (1) \\
"hairbrush" (1) \\
"moss" (1) \\
"nail" (1) \\
18 metaphors
\end{tabular}

The metaphors suggested by the great majority of pre-service science teachers $(\mathrm{f}=29)$ were gathered under the "function similarity" category, the first category. Pre-service science teachers generally emphasized the protecting function of the trichome which is one of the functions of the trichome in their metaphors. An example of the "mother" metaphor with the highest frequency among these metaphors is as follows;

"Trichomes are like a mother, because mothers protect their children from harmful things. Trichomes protect plants from things that would harm them".

When the evaluated both techniques together, the model about the cognitive structure of pre-service science teachers on the concept of trichome was created (Figure 2). The categories obtained from word association test and metaphor technique were shown in this model. Moreover common 2 categories in both techniques, dominant category in these common categories, the most emphasized function of trichome, the categories in which misconception were determined were also shown in this model. 


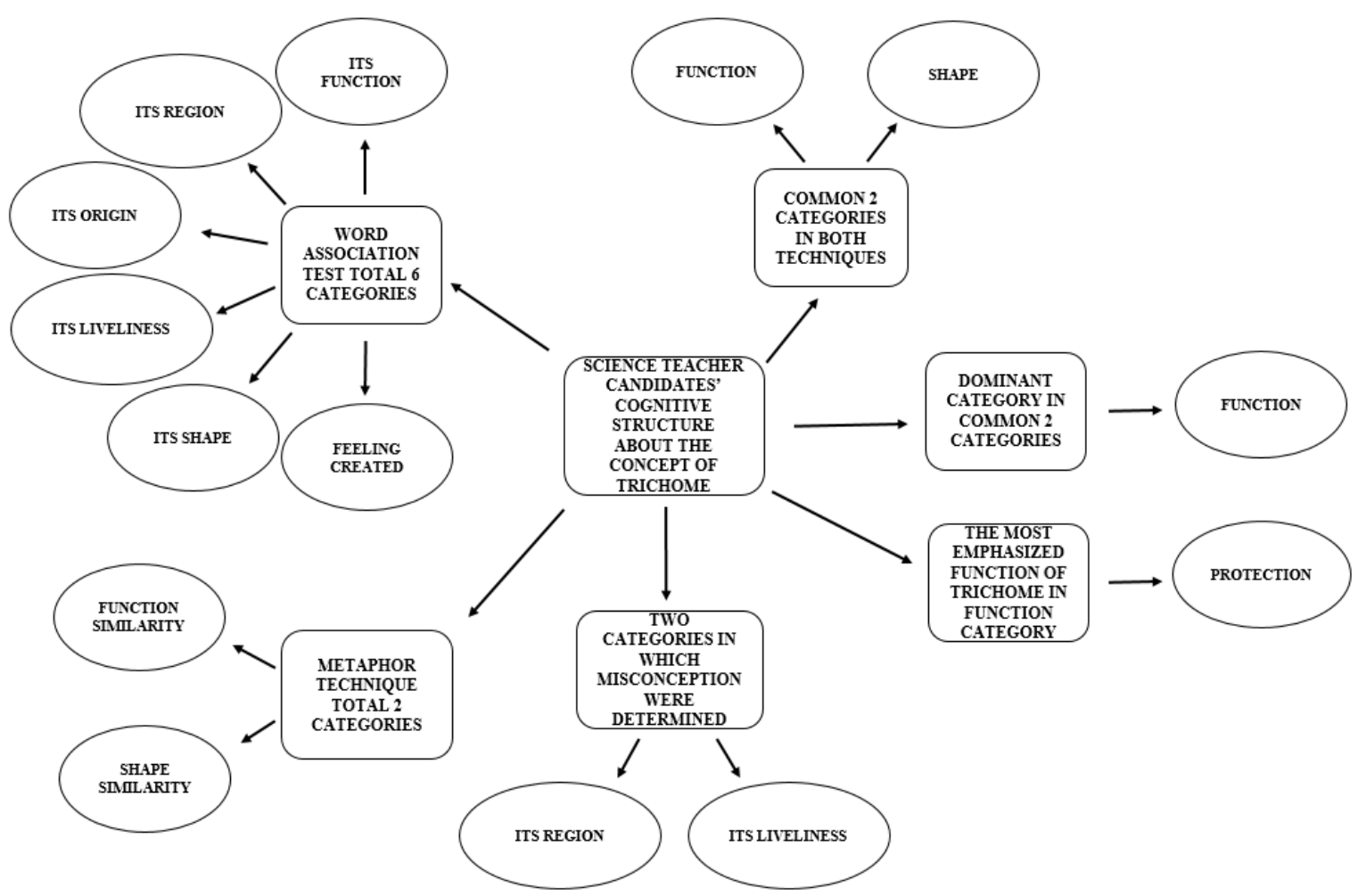

Figure 2. Pre-service science teachers' cognitive structure about trichome

\section{Results, Conclusions and Recommendations}

This study was prepared to determine pre-service science teachers' cognitive structures related to stoma and trichome from plantal epidermal structures.

In the study, pre-service science teachers' cognitive structures related to stoma were gathered under a total of 6 categories ("its working mechanism", "its anatomical structure", "its region", "its permeability", "its function" and "its shape" in the word association test and under a total of 3 categories ("working mechanism similarity", "function similarity" and "shape similarity") by the metaphor technique. Pre-service science teachers' cognitive structures related to tricome were gathered under a total of 6 categories ("its function", "its region", "its origin", "its liveliness", "its shape" and "feeling created") in the word association test and under a total of 2 categories ("function similarity" and "shape similarity") by the metaphor technique. The categories obtained by both measurement tools support and detail each other. This situation supports the opinion of Kurt and Ekici (2013) that "Detailed information can be obtained about the cognitive structure of the same subject using different measurement tools that support each other".

Furthermore, as a result of the word association test for the concepts of both stoma and trichome, the words of "plant", "leaf" and "epiderm" emerged as the words which had high frequencies and were commonly repeated. This situation indicates that the presence of both structures in the epiderm layer of the plant's leaves has been learned by pre-service science teachers and that they have put it in their cognitive structures. Besides, trichome in plants has not only the function of protecting but also the functions of secretion, absorption and adsorption. However, when pre-service science teachers were asked to make an analogy related to "trichome", the trichome's function of sucking was emphasized just by one pre-service science teacher with the analogy of "pipette", other pre-service science teachers focused on just one function of the trichome (protection). A similar situation was also determined in metaphors suggested for the concept of the stoma. Here, analogies were mostly made for the opening and closing mechanism of the stoma. This situation indicates that analogy is made based on the most obvious and most well-known aspects of the phenomenon compared.

In addition, as a result of the word association test for the concept of trichome, the word of "dog" which is included in the category of "its region" was suggested by quite a large number of pre-service science teachers $(f=10)$. This suggested word indicates that the "hair" in animals was confused with feather, and these pre-service science teachers had misconceptions. Furthermore, the fact that the words of "live" and "lifeless" which were suggested in the "its liveliness" category were almost equal in number indicates that pre-service science teachers could not fully make a distinction about whether trichome is live or lifeless. As a result of the word association test for the concept of the stoma, none of the participants suggested the word of 
"water vapor" that should be included in the "its permeability" category although $\mathrm{CO}_{2}$ and $\mathrm{O}_{2}$, as well as water vapor, pass through the pore of stoma. The passage of $\mathrm{CO}_{2}$ and $\mathrm{O}_{2}$ mostly came to their mind. In addition to this in the same category the suggestion of the word of "nutrition" by five pre-service science teachers shows that they had misconception because just water vapor, $\mathrm{CO}_{2}$ and $\mathrm{O}_{2}$ pass through the pore of stoma.

Moreover, the word of "selective permeability" which was expressed by a pre-service science teacher based on the opinion that the pore of stoma has a membrane and this membrane regulates the input and output according to the feature of selective permeability indicates that this pre-service science teacher had a misconception.

Stoma provides the transfer of $\mathrm{CO}_{2}$ which is necessary for the plant's photosynthesis from air to leaves, and also provides the transfer of $\mathrm{O}_{2}$ which is formed by photosynthesis from leaves to the atmosphere, and is essential for photosynthesis. However, the fact that this connection between photosynthesis and stoma concepts could not be fully established by pre-service science teachers was understood by the fact that the word of "photosynthesis" was suggested just by five students in the word association test. Although it was determined that students had numerous misconceptions in many studies carried out on photosynthesis (Canal 1999; Tekkaya and Balc1 2003; Marmaroti and Galanopoulou 2006; Köse 2008), such a conceptual connection could not be found for the determination of the relationship between photosynthesis and stoma in participants in these studies. To what extent the word association test is effective in revealing the connections between the concepts of the subjects given to students has been demonstrated once again by this study.

With this study, pre-service science teachers' cognitive structures revealed with the word association test have been further detailed with the metaphor technique.

The inadequacies observed in the cognitive structures of pre-service science teachers about stoma and trichome and some of the misconceptions detected may be the result of both the education they have taken so far and the inadequacies in the study disciplines. But this is more important when they become a teacher. In order to prevent this situation, conceptual learning should be given importance at every level of education.

In addition, educational activities that will be carried out by making comments and creating a discussion environment without memorization will lead to a better establishment of relations between the concepts and as a result, meaningful learning.

Word association test and metaphor technique was used together in this study. If these two techniques can be applied to students at the beginning of the course and at the end of the course, it will be determined both the level of readiness of the students at the beginning of the course and the cognitive structure competencies shaped at the end of the course. In this way with using these two techniques, it can be understand how the cognitive structure of students is formed in any subject of biology courses and how much information given by teacher stiches in students' minds.

Moreover it is believed that the use of both techniques together will support each other in cognitive structure determination studies to be carried out in the future.

\section{REFERENCES}

[1] Atasoy, B. (2004). Science Learning and Teaching, Ankara: Asil Yayınevi.

[2] Bahar, M., Özatl1, N. S. (2003). Investigation of the cognitive structure of high school 1st grade students about the subject of primary components of beings with word association test. Journal of Ballkesir University Institute of Science and Technology, 5(1), 75- 85.

[3] Bahar, M., Johnstone, A. H., Sutcliffe, R. G. (1999). Investigation of students' cognitive structure in elementary genetics through word association tests. Journal of Biological Education, 33, 134-141.

[4] Bahar, M., Ozel, M., Prokop, P., Usak, M. (2008). Science student teachers' ideas of the heart. Journal of Baltic Science Education, 7(2), 1648-3898.

[5] Canal, P. (1999). Photosynthesis and 'inverse respiration' in plants: An inevitable misconception? International Journal of Science Education, 21(4), 363-371.

[6] Cardellini, L., Bahar, M. (2000). Monitoring the learning of chemistry through word association tests. Australian Chemistry Research Book, 19, 59- 69.

[7] Cimer, A. (2012). What makes biology learning difficult and effective: Students' views? Educational Research and Reviews, 7(3), 61-71.

[8] Demirci Güler, M. P. (2012). Metaphorical definitions of classroom teacher candidates about science and technology courses. Electronic Journal of Social Science, 11(41), 53-63.

[9] Duit, R. (1991). On the role of analogies and metaphors in learning science. Science Education, 75, 649-672.

[10] Gilbert, J. K., Boulter, C., Rutherford, M. (1998). Models in explanations, part 1, horses for courses? International Journal of Science Education, 20, 83-97.

[11] Hruschka, D. J., Schwartz, D., Cobb St John, D. Piccone-Decaro, E., Jenkıns R. A., Carey, J. W. (2004). Reliability in coding open-ended data: lessons learned from HIV behavioral research. Field Methods, 16(3), 307-331.

[12] Kostove, Z., Radoynovska, B. (2008). Word association test for studying conceptual structures of teachers and students. Bulgarian Journal of Science and Education Policy, 2(2), 209-231.

[13] Köse S. (2008). Diagnosing student misconceptions: using drawings as a research method. World Applied Science Journal, 3, 283-293.

[14] Kurt, H., Ekici, G. (2013). Determining biology student 
teachers' cognitive and alternative concepts on the concept of "Bacteria". Turkish Studies, 8(8), 885-910.

[15] Lukin, K. (2013). Exciting middle and high school students about 1mmunology: An easy, inquiry-based lesson. Immunologic Research, 55(1-3), 201-209.

[16] Marmaroti, P., Galanopoulou, D. (2006). Pupils' understanding of photosynthesis: a questionnaire for the simultaneous assessment of all aspects. International Journal of Science education, 28, 383-403.

[17] Miles, M. B., Huberman, A. M. (1994). Qualitative Data Analysis: An Expanded Sourcebook (2nd ed.). Thousand
Oaks, California: SAGE

[18] Smith, E. L., Blakeslee, T. D., Anderson, C. W. (1993). Teaching strategies associated with conceptual change learning in science. Journal of Research in Science Teaching, $30(2), 111-126$.

[19] Tekkaya, C., Balc1, S. (2003). Determination of students' misconceptions concerning photosynthesis and respiration in plants. Hacettepe University Journal of Education, 24, 101-107.

[20] Yildırım, A., Simsek, H. (2008). Qualitative Research Methods in Social Sciences, Ankara: Seçkin Yayıncılık. 